Masthead Logo

NYLS Journal of Human Rights

Volume 4

Issue 1 Volume IV, Part One, Fall 1986 - Homelessness

Article 15

1986

\title{
The Mentally Disabled and the Law
}

John P. Petrila

Follow this and additional works at: https://digitalcommons.nyls.edu/journal_of_human_rights

Part of the Law Commons

\section{Recommended Citation}

Petrila, John P. (1986) "The Mentally Disabled and the Law," NYLS Journal of Human Rights: Vol. 4 : Iss. 1 , Article 15.

Available at: https://digitalcommons.nyls.edu/journal_of_human_rights/vol4/iss1/15

This Book Review is brought to you for free and open access by DigitalCommons@NYLS. It has been accepted for inclusion in NYLS Journal of

Human Rights by an authorized editor of DigitalCommons@NYLS. 
The Mentally Disabled and the Law. By Samuel Jan Brakel, John Parry, and Barbara A. Weiner. American Bar Association, 1985.

\section{Reviewed by John P. Petrila*}

The Mentally Disabled and the Law is the third edition of a work published by the American Bar Association in 1961 and again in 1971. The authors intended an "encyclopedic" treatment of the law as it affects the mentally disabled. They have succeeded in producing an edition of this now standard work which should be utilized as a basic reference for both the novice and practitioner interested in the many areas subsumed under the heading "mental disability law."

This is an immense volume, covering scores of topics, and reflects the dramatic growth in this field since the last edition of this book. Since that time, a libertarian patients' rights bar, which pursued challenges to state commitment laws and the inadequacies of public mental health institutions in federal courts throughout the country, changed the face of mental health law and, in some cases, treatment. Plaintiffs brought cases with constitutional claims, and as a result of favorable rulings, much of mental health law rests today upon a constitutional footing. For example, civil commitment decisions are perceived now as a deprivation of liberty interests protected by the fourteenth amendment, and are no longer made primarily by psychiatrists. Instead, the process has been legalized, with courts as the principal decision-makers and the subject of the proceeding represented by counsel in what theoretically is an adversarial proceeding. Similarly, the practices of public mental health facilities and their staffs are measured against constitutional norms-patients today have a right to be treated or, conversely, to refuse treatment, grounded in the Constitution.

There have been other dramatic developments in mental health law in the last decade. While constitutional litigation dominated the attention of the courts and the professional literature, malpractice has assumed increasing importance in the

* Deputy Counsel, State of New York, Office of Mental Health. 
scrutiny and regulation of the clinical professions. The most striking developments were court rulings that in certain cases a clinician had a duty to take steps to protect a third party whom the clinician had reason to believe might be endangered by the clinician's patient. The "duty to protect" or "duty to warn" third parties of potential danger forced clinicians to predict dangerousness, a practice that those pursuing reform of civil commitment laws had argued could not be done. Today, claims of patients alleging harmful consequences from the medication prescribed for their care, and the claims of individuals harmed by patients prematurely released from institutions are the subject of increasing numbers of malpractice claims as well.

In the criminal law, the acquittal of John Hinckley spurred new debate over the insanity defense, leading to calls in many places for its repeal or reform. The fact that the Hinckley case was atypical in nearly every way from the stereotypical insanity acquittee's appeared irrelevant in a debate which seemed to give vent to many generalized feelings of dissatisfaction with the entire criminal process and psychiatric participation in it.

Mental health law also moved from the hospital to the community in the 1970s, as mental health systems and patient advocates realized belatedly that the discharge of thousands of patients into the community in the 1960 s and early 1970 s had, in many cases, led to disastrous consequences, primarily because the services needed to sustain former patients in the community had not been developed. The most public symbol of this problem was the homeless, found in every large city, some undefined percentage assuredly mentally ill. Legal battles raged on a variety of fronts once the homeless mentally ill community was discovered. Some believed "reinstitutionalization" was the ideal solution, and proposed state legislation to make civil commitment easier. Others, fearful of this sentiment, filed lawsuits to force state agencies to create housing and other services in the community. A third group, seeking to develop community resources, fought with an often resistant public over exclusionary zoning laws which made such development difficult.

The principal strength of The Mentally Disabled and the Law is that it manages in a very readable fashion to cover each of these sweeping developments in the law. The authors discuss, in separate chapters, involuntary hospitalization, voluntary ad- 
missions, discharges and transfers, patients' rights, incompetency and surrogate decisionmaking, family-law issues, confidentiality and general liability, community-based rights and entitlements (including access to education and housing), and criminal law and the mentally disabled. Scores of related topics are discussed within each chapter. Significant judicial opinions and statutory law, both federal and state, provide the underpinning for the discussion of each topic. However, the book is not simply a dry recitation of law. For example, in the discussion of confidentiality one finds references to the formal ethical principles of the concerned professional organizations, an effective way to round out coverage of an issue that is not simply legal in nature. In addition, the historic development of the particular area of law is at least noted, which provides the reader with useful perspective. At the end of each chapter, tables are included which list by state the statutory references to many of the topics covered in the preceding chapter. There are nearly sixty such tables, which are useful starting points for the student or professional interested in learning the way the various jurisdictions treat particular subjects.

An advantage to revamping this work every ten to fifteen years is that it gives the authors the opportunity to reflect upon accumulated law, something they cannot do with other methods of updating, such as the use of pocket-parts. For example, the use of sexual psychopathy laws has fallen into disfavor, with many states repealing statutes that once mandated special dispositional alternatives for those so labeled. As a result, this subject is treated in relatively little space, in contrast to the 1971 edition when it received a separate chapter. Conversely, there has been an explosion of legal activity with community-based issues, including housing, personal finance, zoning and education, and the authors, wisely, have written an entirely new chapter devoted exclusively to these issues. The reader, then, can get a definite sense of movement within the law. One also can read this book confident that if something significant in mental disability law has happened in a particular area of interest after 1971 , it is at least noted by the authors.

The largely successful effort by the authors to provide encyclopedic coverage of a subject matter that is growing in volume both vertically and horizontally is also the cause of the book's 
flaws. First, the tables address only statutory law. As Brakel notes in his introduction, administrative regulation is a very significant source of operational and procedural law. He indicates that the authors considered including this pertinent information, but abandoned the idea because of size and time limitations. In addition, the coverage of case law from each state is not exhaustive. Emphasis is necessarily given to the major cases shaping a particular area of law. As a result, the reader with a more than general interest in a particular subject should approach this work as a starting point only. The tables, in most instances, provide statutory coverage only through 1982 , so a number of the references may already be dated.

Second, the organization in at least one critical instance is problematic. The authors have chosen to include one chapter titled "Rights of Institutionalized Persons" and another titled "Treatment Rights." The former treats discrete personal rights retained by hospitalized patients like the rights to communication, religious freedom, humane care, and to an appropriate use of restraint and seclusion. The latter chapter addresses constitutional rights to treatment and to refuse treatment. Each chapter addresses seminal lower court decisions like Wyatt v. Stickney (first articulating a constitutionally-based right to treatment) and later Supreme Court decisions like Donaldson v. O'Connor (holding that an individual cannot be confined in an institution if able to live in the community safely, either alone, or with the assistance of others) and Youngberg v. Romeo (holding that a mentally retarded patient retains liberty interests sufficient to afford him freedom from any restraints that hinder the exercise of those interests). Yet nowhere is there a comprehensive discussion of the evolution of the right to treatment ("habilitation" in the context of the mentally retarded and developmentally disabled). Our understanding of the meaning of the right has changed markedly, from the mid-1970s when federal courts enacted a broad-based right by which the courts set very specific standards for the provision of institutional services, to the present, when the federal courts, taking their cue from the United States Supreme Court, have adopted a much more restrained attitude toward state mental health (and correctional) systems. An understanding of this evolution is important, both because of the core position the right to treatment holds in mental health 
law, and because the increasing conservatism of the federal courts in this area explains in large part the turn of patient advocates to state court.

The authors do note the trend among state legislatures to codify patient rights first won in litigation. The precise definitions of rights articulated by state legislatures, with the increased conservatism of federal courts as noted above, has hastened the turn to state court in patient rights litigation. This development is not discussed by the authors. It might have been useful if the authors had devoted at least some space to discussing these developments, and to giving their prediction as to where the law might go in the next decade.

Finally, the book lacks a coherent viewpoint toward its subject matter. Brakel, in the introduction, expresses the hope that this work will help to promote a consensus when a variety of approaches to an issue have been tried. However, he also notes that individual credit for each chapter has been assigned because the authors have chosen not to reconcile their differences of philosophy and opinion. Yet, a unified viewpoint might have made this book more persuasive than it is (or even intends to be) in advocating one or another approach in dealing with a particular issue. This absence of cohesion to a single point of view makes the book an objective reporter of the state of the law, however, the same trait also makes it less persuasive for the reader.

These criticisms, minor given the size of this work, are not meant to detract from the accomplishments of the authors. The Mentally Disabled and the Law is a very impressive, and in many ways, essential source of research. Its achievements have been recognized: the American Psychiatric Association awarded the authors its 1986 Guttmacher Award, given annually for the most significant contribution to mental health law literature. The volume provides the reader with more useful information on mental health law, in one source, than he or she can find elsewhere. For that reason alone, this should be a much-used reference in the library of anyone interested in mental health law. 
